\title{
The Carbon Sequestration Potential of Soils: Some Data from Northern Italian Regions
}

\author{
Ciro Gardi ${ }^{1 *}$, Stefano Brenna ${ }^{2}$, Silvia Solaro ${ }^{2}$, Mauro Piazzi ${ }^{3}$, Fabio Petrella ${ }^{3}$ \\ ${ }^{1}$ Dipartimento di Scienze Ambientali, Università di Parma \\ Parco Area delle Scienze 33A, 43100 Parma, Italy \\ ${ }^{2}$ ERSAF Lombardia, Via Copernico 28, 20125, Milano, Italy \\ ${ }^{3}$ IPLA, Corso Casale 476, 10132 Torino, Italy
}

Received: 2 December 2006. Accepted: 2 January 2007

\begin{abstract}
It is well known that soil plays, within terrestrial ecosystems, an essential role in many biogeochemical cycles and in the regulation of greenhouse gas fluxes. Less known, and often underestimated, is the importance of carbon sequestration potential of soil, especially trough humified carbon. Even within the agro-forestry practices of the Kyoto Protocol, most of the attention is devoted to the biomass carbon storage, rather than soil carbon sequestration. The highest potentialities for carbon sequestration are related to the arable lands, that accounts for the $11 \%$ of earth surface; the increase of $0.1 \%$ of organic carbon content in the $0-30 \mathrm{~cm}$ layer of cultivated soils, achievable with minor adjustment of agronomic practices, is equivalent to the sequestration of 5,000 millions $\mathrm{t}$ of carbon. On the other hand, the conversion of a grasslands into cultivated land determine, during 50-70 years, a release of 80-150 t CO $\mathrm{ha}^{-1}$. Within this paper the estimate of soil organic carbon of three Northern Italian regions is presented.
\end{abstract}

Key-words: soil organic carbon, carbon stock, Kyoto protocol, land use, carbon sink.

\section{Introduction}

The global soil carbon pool is estimated in 2500 gigatons (Gt), that includes about $1550 \mathrm{Gt}$ of soil organic carbon (SOC) and $950 \mathrm{Gt}$ of soil inorganic carbon (SIC) (Lal, 2004). Other pools on the earth are much larger, but they are relatively stable; the sedimentary rocks store about 100 milions Gt of carbon and it is estimated that the deep ocean can store 40,000 Gt of carbon, but the fluxes generated from these pools are negligible. On the contrary soil carbon pool is larger than other active pools; soil $\mathrm{C}$ pool is estimated between 2 and 3 times the size of the atmospheric pool (760 Gt) (Eswaran et al., 1993; Post et al., 1982; Lal, 2004) and 4.5 times the size of the biotic pool (560Gt) (Lal, 2004).

Carbon (C) sequestration in soils is gaining increasing acceptance as a mean to reduce net carbon dioxide $\left(\mathrm{CO}_{2}\right)$ emissions into the atmosphere even if it is necessary to improve our understanding of the SOC stocks and the processes contributing to $\mathrm{C}$ storage in soils.

In general terms the SOC stock to $1 \mathrm{~m}$ depth ranges from $30 \mathrm{t} \mathrm{ha}^{-1}$ in arid climates to $800 \mathrm{t}$ $\mathrm{ha}^{-1}$ in organic soils in cold regions, and a predominant range of 50 to $150 \mathrm{t} \mathrm{ha}^{-1}$ (Lal, 2004). The size of the SOM pool indicates that even small changes in the global stock of SOM could cause a significant change in atmospheric $\mathrm{CO}_{2}$, and, consequently, the global $\mathrm{C}$ cycle (Schimel et al., 1994). Thus, one of the largest terms of the global $\mathrm{C}$ balance is the exchange of $\mathrm{C}$ between soils and the atmosphere.

Land use in general and particularly agricultural practices can significantly influence soil carbon storage. The conversion of forest and pastureland into cropland is known to deteriorate soil properties, especially reduce SOC and change the distribution and stability of soil aggregates (Ross, 1993; Singh and Singh, 1996). Among the agricultural soil other factors can affect the soil organic matter balance, such as tillage operations, manure and fertiliser application and crop rotation, land use change (FordRobertson et al., 1999; Schrot et al., 2002, Fearnside, 1997; Katterer and Andrén, 1999). Reduction in tillage and no tillage generally led to organic carbon accumulation in the soil (Lal et al.,

* Corresponding Author: Tel.: +39 521 905692; Fax: +39 521 906611. E-mail address: ciro.gardi@unipr.it 
1994; Campbell et al., 1995; Paustian et al., 1997). A review on the carbon sequestration in the agricultural soils of Europe (Freibauer et al., 2004), indicates a range of SOC sequestration rate between $0.2-0.3 \mathrm{t} \mathrm{C} \mathrm{ha}^{-1}$ year $^{-1}$ for the sludge application or the appropriate management of crop residues, and $1.9 \mathrm{t} \mathrm{C} \mathrm{ha}^{-1}$ year $^{-1}$, for the conversion of arable land into grassland. Efficient carbon sequestration in agricultural soils requires a permanent management change and a deep knowledge of soils in order to allow selection of areas with high carbon sequestering potential (Freibauer et al., 2004). Moreover the need for accurate information on the organic matter (OM) content in soils at European, National or Regional level has been increasing steadily over the past few years and it has been outlined by the European Soil Bureau. The aim of this study is to provide data on the assessment of SOC stock or concentration of three Northern Italian region and to describe the approach used for these surveys.

\section{Materials and methods}

In Figure 1 is shown the study area, together with the main geographic feature of the three investigated regions.

\section{Piemonte}

The estimate of SOC stock was carried out by the Institute for the Wood plants and the Environment (IPLA), on the base of the existing soil survey data and using the 1:250,000 soil map. The soil survey data selected for this research were characterized at least by the following parameters:

- geographic coordinates

- land use classification

- horizon description

- soil classification.

Bulk density was estimated using the Baumer (1992) equation; the estimates of SOC stock were referred to the $0-30 \mathrm{~cm}$ soil layer.

The SOC of each unit of the 1:250,000 soil map, was calculated as the average of all the observation available in the unit. A total of 2,546 SOC data have been used, while other data needed for SOC stock computation, such as the skeleton content, were available for more than 9,000 sampling points.

\section{Lombardia}

SOC values have been estimated on the base of the 1:250.00 geographic data base of the regional agency for agriculture and forestry (ERSAF); bulk density data were estimated apply-

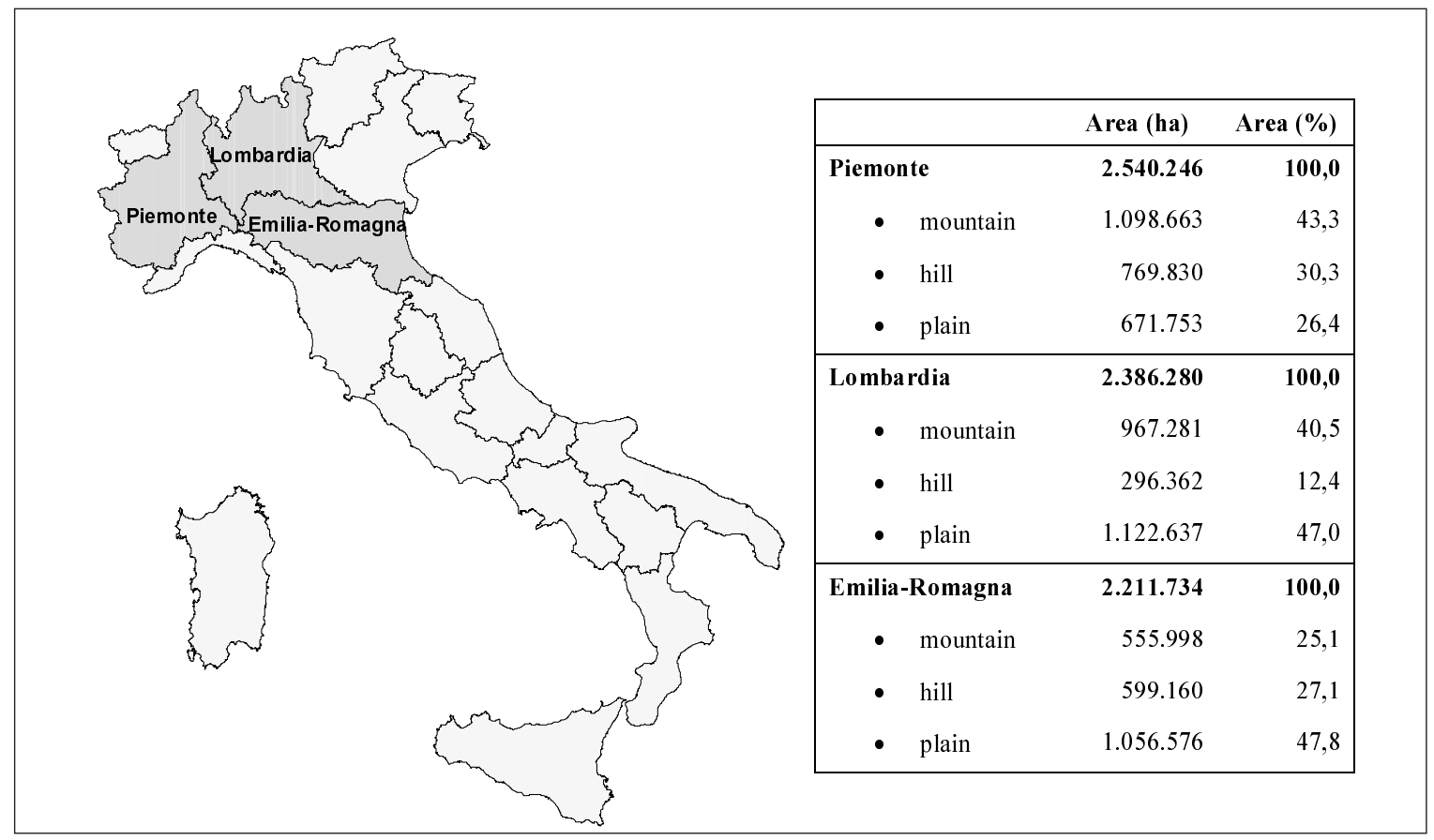

Figure 1. Study area and main geographic feature of the investigated regions. 
ing the Hollis (1995) pedotranfers function. The final calculation of the total content of SOC was carried out using the Batjes (1996a) equation:

$$
\mathrm{Td}=\Sigma[\rho \mathrm{i} \cdot \mathrm{Pi} \cdot \mathrm{Di} \cdot(1-\mathrm{Si})]
$$

where

$\mathrm{Td}=$ total organic carbon content $\left(\mathrm{Mg} \mathrm{m}^{-2}\right)$

$\rho \mathrm{i}=$ bulk density of $i$ layer $\left(\mathrm{Mg} \mathrm{m}^{-3}\right)$

$\mathrm{Pi}=$ organic carbon content of $i$ layer $\left(\mathrm{g} \mathrm{C} \mathrm{g}^{-1}\right.$ fine hearth)

$\mathrm{Di}=$ depth of $i$ layer $(\mathrm{m})$

$\mathrm{Si}=$ volume $(\%)$ of fragments $>2 \mathrm{~mm}$ in the $i$ layer.

The next step was the evaluation of the SOC stock, at territorial level, multiplying the average SOC content of each cartographic unit, for its effective area, that means excluding the nonsoil area.

A total number of 5,200 SOC data have been used in order to define the average SOC content for 322 cartographic units.

\section{Emilia-Romagna}

The analysis on Emilia-Romagna soils used in this research, were limited to the alluvial plain territory and consist in the spatialization of 9,667 sampling points, selected from a data set of 13,277 samples, while the evaluation of SOC stock is in progress. Spatial interpolation was carried out using both, kriging and simulation approach; the objective of spatial interpolation was to obtain both an estimation of Soil Organic Matter (SOM) content and quantify the uncertainty of the estimates. Kriging based approach are more suitable to model the local uncertainty, while the simulation (parametric and non-parametric) are aimed to model spatial uncertainty. For the simulation were applied and compared two approach: parametric (Sequential Gaussian Simulation) and non parametric (Sequential Indicator Simulation) (Ungaro et al., 2005).

\section{Results}

\section{Piemonte}

The map of Figure 2 shows the SOC content of Piemonte soils, in the $0-30 \mathrm{~cm}$ layer. The territory is classified according to 6 classes of SOC content; the most frequent classes are 30-50 and 50-70 t C ha-1, where the second one represent

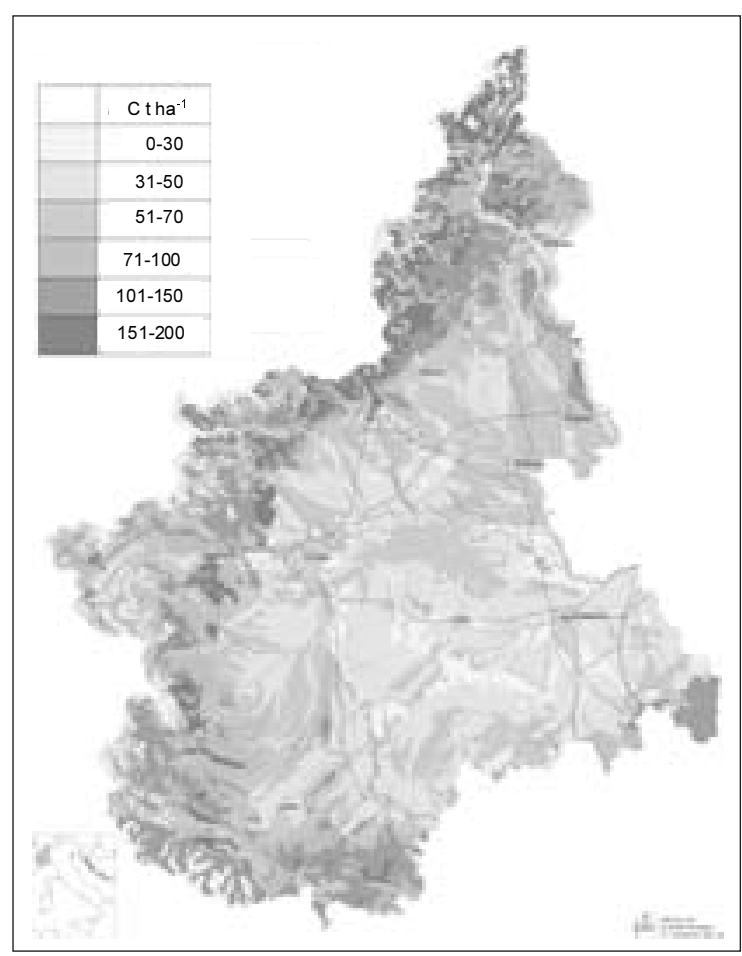

Figure 2. Soil organic carbon (SOC) content of Piemonte soils.

also the modal class. The SOC content was classified also on the base of the physiography of the territory, giving the results shown in Table 1. The lowest concentration (\%) and content (t $\mathrm{ha}^{-1}$ ) of SOC was found in the hilly area and not in the plain; this is probably due to the wide diffusion of intensive vineyards on the hilly area and to the effects of the intensive agronomic management of these soils.

The average SOC content of forested areas and the carbon stored in forest biomass, necromass and litter, were also estimated (Tab. 2).

With a GIS spatial analysis, based on soil and land use data set, it was possible estimate that forest soils store on average $85 \mathrm{t} \mathrm{C} \mathrm{ha}^{-1}$, while in these areas the total contribution of biomass, necromass and litter is $87 \mathrm{t} \mathrm{C} \mathrm{ha}^{-1}$. These data

Table 1. SOC content within the main physiographic region of Piemonte.

\begin{tabular}{lcc}
\hline & \multicolumn{2}{c}{$\begin{array}{c}\text { Soil organic carbon } \\
(0-30 \mathrm{~cm})\end{array}$} \\
\cline { 2 - 3 } & $\%$ & $\mathrm{t} \mathrm{ha}^{-1}$ \\
\hline Mountain & 3.10 & 112 \\
Hill & 1.15 & 45 \\
Plain & 1.58 & 55 \\
\hline
\end{tabular}


Table 2. Soil and forest biomass organic carbon stock in Piemonte.

\begin{tabular}{lc}
\hline & Carbon stock (Mt) \\
\hline Soil & 175 \\
mountain & 105 \\
hills & 19 \\
plain & 51 \\
Forest & 79 \\
above ground biomass & 54 \\
below ground biomass & 11 \\
litter & 7 \\
necromass & 7 \\
Total & 254 \\
\hline
\end{tabular}

are in agreement with the general estimate on the ratio of soil/biomass carbon storage reported for temperate forest (Robert and Saugier, 2003). The comparison of SOC content of forest soil $\left(85 \mathrm{t} \mathrm{ha}^{-1}\right)$ with the average content of mountain area $\left(112 \mathrm{t} \mathrm{ha}^{-1}\right)$, allow to conclude that mountain grasslands should have a SOC content much higher than forest, within a range of 135-140 $\mathrm{t} \mathrm{ha}^{-1}$. In fact in this physiographic region $39 \%$ of the area is covered by forest, and the remaining area is represented almost entirely by grasslands. The total storage of SOC of the region is $175 \mathrm{Mt}$ (Tab. 2), corresponding to an average of $81 \mathrm{t} \mathrm{ha}^{-1}$; among the physiographic region, mountain has the largest stock, contributing for the $60 \%$ of the total.

\section{Lombardia}

The map of Figure 3 shows the SOC of Lombardia soils, in the $0-30 \mathrm{~cm}$, classified according

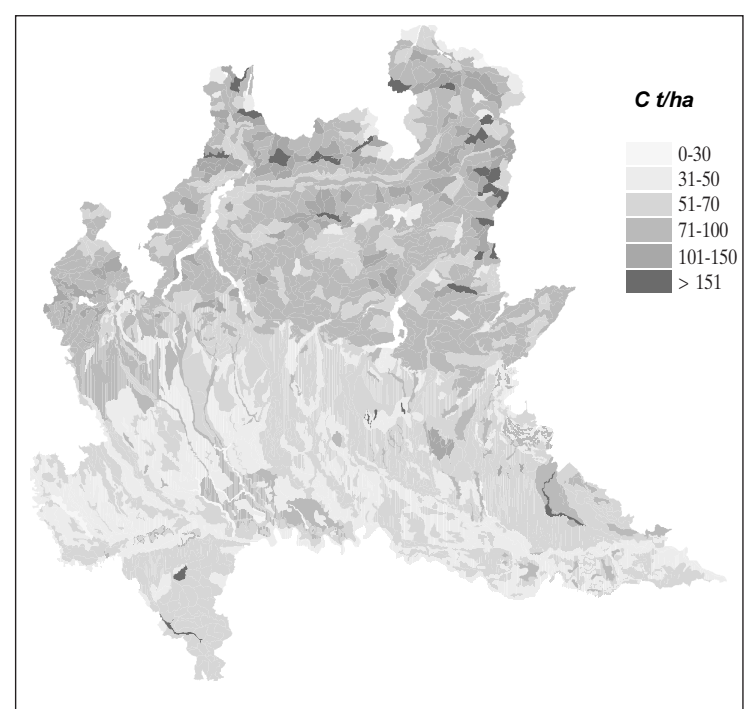

Figure 3. Soil organic carbon (SOC) content of Lombardia soils. to the same principle described for Piemonte region. The frequency distribution is similar, and also the modal class is the $50-70 \mathrm{t} \mathrm{C} \mathrm{ha}^{-1}$.

The average SOC content, referred to five different soil depth, were calculated for each pedological region (Fig. 4) and for each soil type
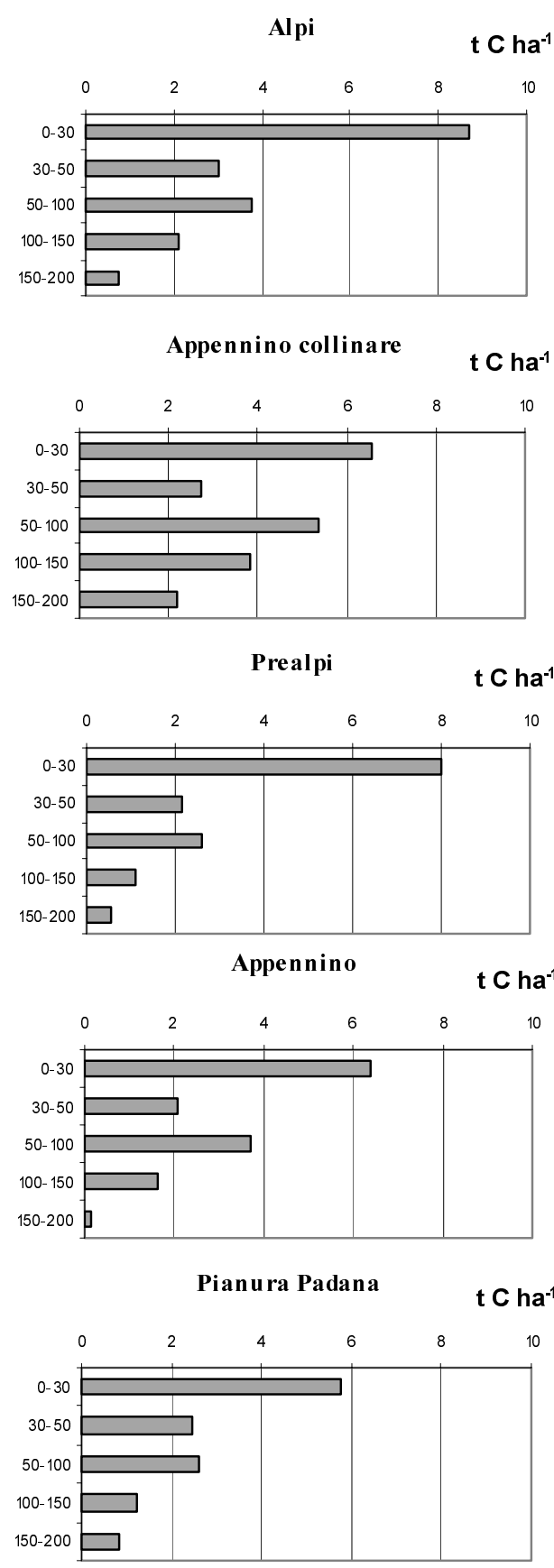

Figure 4. Soil organic carbon profile for the five pedological regions of Lombardia. 

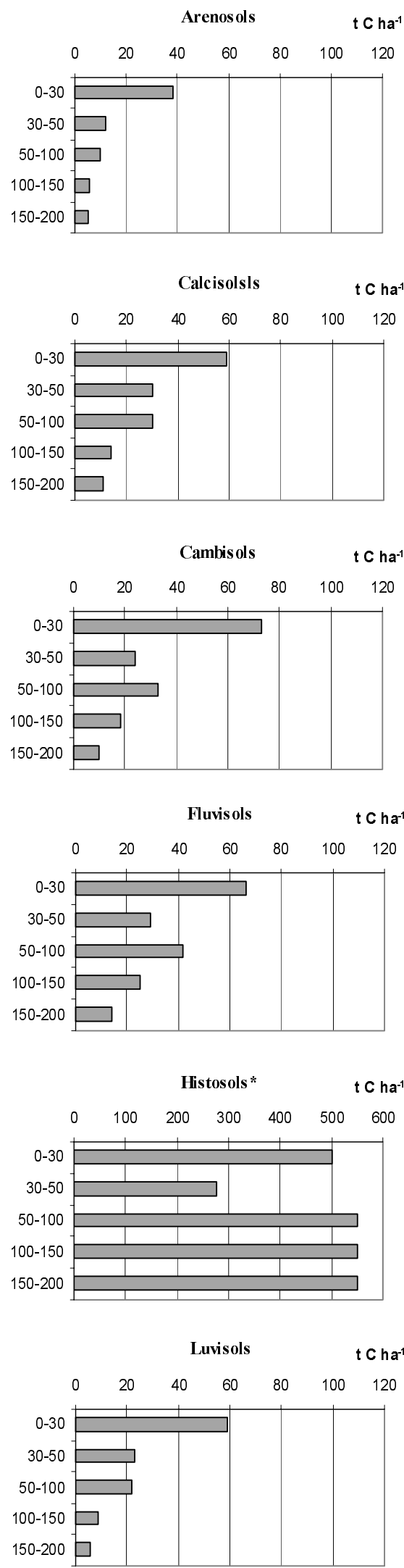
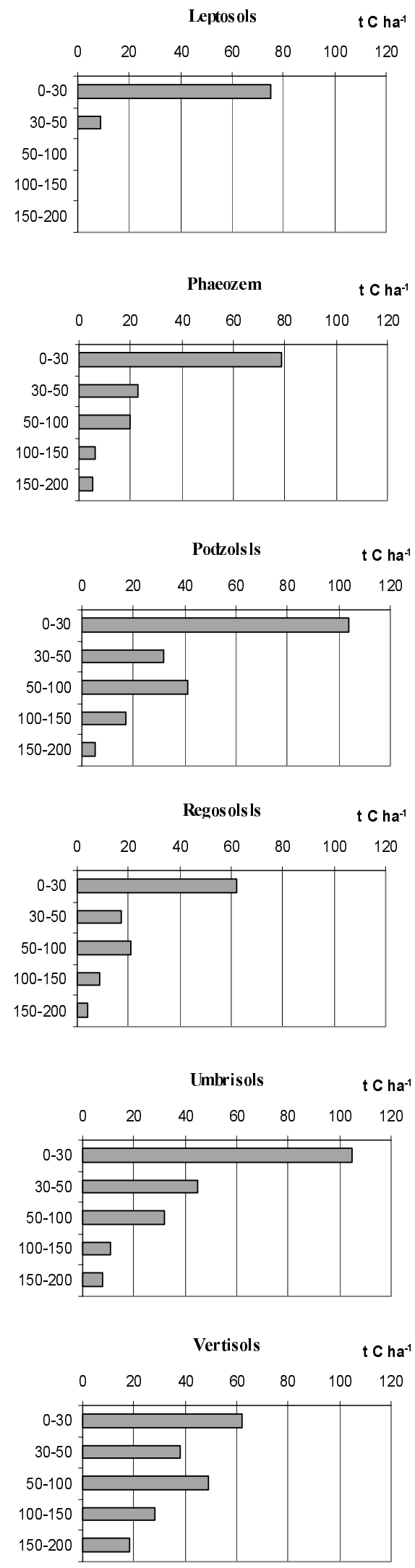

Figure 5. Soil organic carbon profile for the main WRB soil types of Lombardia (* Histosoos carbon content is in different scale). 
Figure 6. Soil organic matter distribution in the soils of EmiliaRomagna plain.

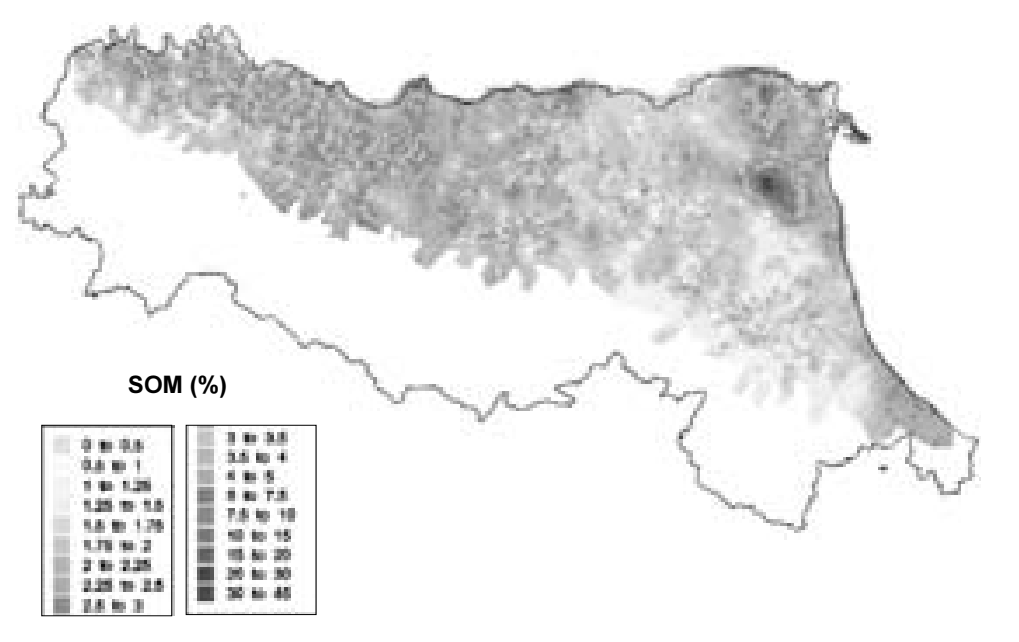

(Fig. 5), classified according to WRB (IUSS, 2006), present in the study area. Soils of mountain area were characterized by the highest SOC content showing a clear direct relationship with the mean elevation of the pedological regions; however the soils of these pedological regions are often shallow, as can be observed from the variation of SOC content with depth, and this factor represent a limit for the carbon stock potential. In fact if we consider the storage of SOC in the 0-200 cm depth, soils of Appennino collinare pedological region store more carbon than soil of Alpi region. The evaluation of SOC stock (Tab. 3) shows the important role of Pianura Padana, where the low SOC content are compensated by the large area of this region, that account for the $46 \%$ of the carbon stored in the soils of Lombardia.

The estimated SOC content $(0-30 \mathrm{~cm})$ for phaeozem, cambisols and luvisols are respectively 79, 73 and $59 \mathrm{t} \mathrm{ha}^{-1}$ confirming data indicated by Batjes (1992) for the same soil type.
The total storage of Lombardia soils is $130 \mathrm{Mt}$ $\mathrm{C}$, corresponding to an average of $55.8 \mathrm{t} \mathrm{ha}^{-1}$.

\section{Emilia-Romagna}

The results of the spatialization of 9,667 sampling point is reported in Figure 6; the spatial interpolation was realized using the Sequential Gaussian Simulation (Ungaro et al., 2005). The entire investigated territory is characterized by intensive agriculture; consequently the variation in soil organic matter (SOM) within the region reflects both, the distribution of different soil type and the existence of various agricultural type. The spot of high SOM concentration in the north-eastern part of the region, is due to organic soils of former wetlands reclaimed, in the recent past, for agricultural use, while the gradient of SOM from the western to the eastern part of the region is mainly due to the intensity of animal husbandry and the practice of manuring.

A descriptive statistical analysis of SOM, is

Table 3. Soil organic carbon stock in Lombardia.

\begin{tabular}{lrrrrr}
\hline & \multicolumn{5}{c}{ Pedological regionSoil carbon stock (Mt) } \\
\cline { 2 - 6 } & $0-30 \mathrm{~cm}$ & $0-50 \mathrm{~cm}$ & $0-100 \mathrm{~cm}$ & $0-150 \mathrm{~cm}$ & $0-200 \mathrm{~cm}$ \\
\hline Alpi & 36 & 49 & 64 & 73 & 76 \\
Prealpi & 30 & 38 & 48 & 52 & 54 \\
Pianura Padana & 60 & 85 & 112 & 125 & 134 \\
Appennino collinare & 3 & 4 & 7 & 8 & 9 \\
Appennino & 1 & 1 & 2 & 2 & 275 \\
Lombardia & 130 & 177 & 233 & 260 & 2 \\
\hline
\end{tabular}


Table 4. Descriptive statistics of SOC of the administrative districts of Emilia-Romagna.

\begin{tabular}{|c|c|c|c|c|c|}
\hline \multirow[t]{2}{*}{ Agricultural districts } & \multicolumn{5}{|c|}{ Soil organic carbon $(\%)$} \\
\hline & Observation & Mean & Minimum & Maximum & Std. dev. \\
\hline Pianura piacentina & 1178 & 1,24 & 0,11 & 5,86 & 0,39 \\
\hline Pianura parmense & 2038 & 1,40 & 0,23 & 2,87 & 0,36 \\
\hline Pianura reggiana e modenese & 1787 & 1,24 & 0,11 & 4,37 & 0,37 \\
\hline Pianura bolognese e alto ferrarese & 2389 & 1,02 & 0,17 & 2,82 & 0,26 \\
\hline Basso ferrarese & 262 & 2,33 & 0,17 & 23,39 & 3,68 \\
\hline Pianura romagnola e riminese & 1413 & 0,95 & 0,29 & 7,13 & 0,34 \\
\hline Whole area & 9667 & 1,21 & 0,11 & 23,39 & 0,74 \\
\hline
\end{tabular}

reported in Table 4; the regional territory have been divided into agricultural districts. The high variability of SOM values within territories relatively homogeneous from pedological point of view (except than Ferrara), demonstrate the existence of a potential to increase the SOM (and SOC) stocks by adapting the appropriate agronomic practices.

\section{Discussion}

Data presented are comparable with SOC stocks and contents reported in literature for similar geographic situation (Sleutel et al., 2003; Rusco et al., 2001; Batjes, 1996b). The values indicated for the different pedological or physiographic units are the results of a mix of land use. In the alluvial plain (Pianura Padana) arable lands represent almost the entire non urban area, in the hilly area land use is represented by a mosaic of arable lands, grasslands and forests and in mountain land use is represented by grasslands and forests. Having in mind these considerations we can easily compare values presented in this paper, with data reported in literature for different biomes. For grassland of temperate regions are reported SOC stocks, in the 0-30 cm layer, ranging between 60 and 150 t ha $^{-1}$ (Leifeld et al., 2004; Robert and Saugier, 2003), forest soils range between 70 and 150 t ha-1 (Pignard et al., 2000; Robert and Saugier, 2003), while the upper layer of arable lands can store between 50 and $80 \mathrm{t} \mathrm{ha}^{-1}$ of organic carbon (Leifeld et al., 2004; Arrouays et al., 2001).

Within soil of the alluvial plain the SOC variability can be explained by the difference in soil characteristics (mainly texture and water regimen - Leifeld, 2004) and in agronomic management. Data from Lombardia showed a range of 21.8 and $120.4 \mathrm{t} \mathrm{ha}^{-1}$, in the 0-30 cm layer for the units of Po valley; these data however, are the average of the entire cartographic unit, representing only a part of the total variability. More information can be derived from the Emilia-Romagna data set; the range of these values (expressed as SOM content of the Ap horizon) is between 0.11 and $7.13 \%$, if we exclude the "Basso ferrarese" peat soils.

Mountain soils (Piemonte and Lombardia), showed the highest SOC concentration in the 0$30 \mathrm{~cm}$ layer, confirming the well known positive correlation between SOC and elevation (Vos and Stortelder, 1992).

\section{Conclusions}

Within the regions considered in the present study, soils of alluvial plain area showed to have the greater potential to increase the carbon stock. In fact, even if the mountain soils are characterized by the highest $\mathrm{C}$ concentration or, in case of Piemonte, by the larger stock, they are often in climax condition, with limited possibility to increase further the organic carbon content. On the contrary, intensive agriculture soils of plain or hilly area can increase the organic carbon content, by the adoption of minor adjustment in agronomic practices.

\section{References}

Arrouays D., Deslais W., Badeau V. 2001. The carbon content of topsoil and its geographical distribution in France. Soil Use Manage, 17:7-11.

Batjes N.H. 1996a. Development of a world data set of soil water retention properties using pedotransfer rules. Geoderma, 71:31-52.

Batjes N.H. 1996b. Total carbon and nitrogen in the soils of the world. Eur. Journal of Soil Science, 47:151-163.

Batjes N.H., Bridges E.M. (eds.) 1992. World Inventory of Soil Emission Potentials. Proceedings of International Workshop organised in the framework of the 
Dutch National Research Programme on Global Air Pollution and Climate Change, (24-27 August 1992, Wageningen). ISRIC, Wageningen, $122 \mathrm{pp}$.

Baumer O.W. 1992. Predicting unsaturated hydraulic parameters. In: Leij F.J., Lund L.J. (eds.): Indirect Methods for Estimating the Hydraulic Properties of Unsaturated Soils, 341-355. University of California Press, Riverside.

Campbell C.A., McConkey B.G., Zentner R.P., Dyck F.B., Selles F., Curtin D. 1995. Carbon sequestration in a Brown Chernozem as affected by tillage and rotation. Can. J. Soil Sci., 75:449-458.

Eswaran H., van den Berg E., Reich P. 1993. Organic carbon in soils of the world. Soil Sci. Soc. Am. J., 57:192-194.

Fearnside P.M. 1997. Monitoring needs to transform Amazonian forest maintenance into a global-warming mitigation option. Mitigation and Adaptation Strategies for Global Change, 2:285-302.

Ford-Robertson J., Kimberly R., Maclaren P. 1999. Modelling the effect of land-use practices on greenhouse gas emissions and sinks in New Zealand. Environmental Science \& Policy, 2:135-144.

Freibauer A., Rounsevell M.D.A, Smith P., Verhagen J. 2004. Carbon sequestration in the agricultural soils of Europe. Geoderma, 122(1):1-23.

Hollis J.M., Thanigasalam P., Hallett S.H., Mayr T.R., Jarvis N. 1995. SEISMIC: User manual. Soil Survey and Land Research Centre, Cranfield University, Silsoe, UK.

IUSS Working Group WRB 2006. World Reference Base for Soil Resources 2006. World Soil Resources Reports No. 103, $2^{\text {nd }}$ ed. FAO, Rome, Italy.

Kätterer T., Andrén O. 1999. Long-term agricultural field experiments in Northern Europe: analysis of the influence of management on soil carbon stocks using the ICBM model. Agric. Ecosyst. Environ., 72:165-179.

Lal R. 2004. Soil Carbon Sequestration Impacts on Global Climate Change and Food Security. Science, 304:1623-1627.

Lal R., Stewart B.A. (eds.) 1994. Soil Processes and Water Quality. Lewis Publishers, Boca Raton, FL, 398 pp.

Leifeld J., Bassin S., Fuhrer J. 2004. Carbon stocks in Swiss agricultural soils predicted by land-use, soil characteristics, and altitude. Agricul. Ecosys. Environ., 105:255-266.

Paustian K., Collins H.P., Paul E.A. 1997. Management controls on soil carbon. In: Paul E.A., Paustian K., Elliott E.T., Cole C.V. (eds.): Soil Organic Matter in Temperate Agroecosystems, 15-49. CRC Press, Boca Raton, FL.

Pignard G., Dupouey J.L., Arrouays D., Loustau D. 2000. Carbon stocks estimates for French forests. Biotechnol. Agron. Soc. Environ., 4:285-289.

Post W.M., Emmanuel W.R., Zinke P.J., Stangenberger A.G. 1982. Soil carbon pools and world life zones. Nature, 298:156-159.

Robert M., Saugier B. 2003. Contribution des écosystèmes continentaux à la séquestration du carbone. C.R. Geoscience, 335:577-595.

Ross S.M. 1993. Organic matter in tropical soils: current conditions, concerns and prospects for conservation. Prog. Phys. Geogr., 17:265-305.

Rusco E., Jones R., Bidoglio J. 2001. Organic Matter in the soils of Europe: Present status and future trends. European Commission Directorate General JRC, Joint Research Centre, Institute for Environment and Sustainability, European Soil Bureau.

Schimel D.S., Braswell B.H., Holland E.A., McKeown R., Ojima D.S., Painter T.H., Parton W.J., Townsend A.R. 1994. Climatic, edaphic, and biotic control over storage and turnover in carbon in soils. Global Biochem. Cycles, 8:279-293.

Schrot G., D'Angelo S.A., Teixeira W.G., Haag D., Lieberei R. 2002. Conversion of secondary forest into agroforestry and monocolture plantations in Amazzonia: consequences for biomass, litter and soil carbon stocks after 7 years. Forest Ecol. Manage., 163:131-150.

Singh S., Singh J.S. 1996. Water-stable aggregates and associated organic matter in forest, savanna, and cropland soils of a seasonally dry tropical region. India Biol. Fert. Soils, 22:76-82.

Sleutel S., De Neve S., Hofman G. 2003. Estimates of carbon stock changes in Belgian cropland. Soil Use and Management, 19:166-171.

Ungaro F., Calzolari C., Tarocco P., Giapponesi A., Sarno G. 2005. Quantifying spatial uncertainty of soil organic matter indicators using conditional sequential simulations: a case study in Emilia Romagna plain (Northern Italy). Canadian Journal of Soil Science, 85:499-510.

Vos W., Stortdelder A. 1992. Vanishing Tuscan Landscape: Landscape ecology of a SubmediterraneanMontane area (Solano Basin, Tuscany, Italy). Pudoc Scientific Publisher, Wageningen, 404 pp. 